Ulil norden

\title{
Gender, Education and Population Flows
}

Summary report on knowledge, cross-Nordic experiences and examples from practice 





\section{Gender, Education and Population Flows}

Summary report on knowledge, cross-Nordic experiences and examples from practice

Kathrine Bjerg Bennike, Stine Thidemann Faber and Helene Pristed Nielsen 
Gender, Education and Population Flows

Summary report on knowledge, cross-Nordic experiences and examples from practice

Kathrine Bjerg Bennike, Stine Thidemann Faber and Helene Pristed Nielsen

ISBN 978-92-893-4504-0 (PRINT)

ISBN 978-92-893-4505-7 (PDF)

ISBN 978-92-893-4506-4 (EPUB)

http://dx.doi.org/10.6027/TN2016-514

TemaNord 2016:514

ISSN 0908-6692

(C) Nordic Council of Ministers 2015

Layout: Hanne Lebech

Cover photo: ImageSelect

Print: Rosendahls-Schultz Grafisk

Printed in Denmark

This publication has been published with financial support by the Nordic Council of Ministers. However, the contents of this publication do not necessarily reflect the views, policies or recommendations of the Nordic Council of Ministers.

\section{www.norden.org/nordpub}

\section{Nordic co-operation}

Nordic co-operation is one of the world's most extensive forms of regional collaboration, involving Denmark, Finland, Iceland, Norway, Sweden, and the Faroe Islands, Greenland, and Åland.

Nordic co-operation has firm traditions in politics, the economy, and culture. It plays an important role in European and international collaboration, and aims at creating a strong Nordic community in a strong Europe.

Nordic co-operation seeks to safeguard Nordic and regional interests and principles in the global community. Common Nordic values help the region solidify its position as one of the world's most innovative and competitive.

\section{Nordic Council of Ministers}

Ved Stranden 18

DK-1061 Copenhagen K

Phone (+45) 33960200

www.norden.org 


\section{Contents}

Résumé - UK

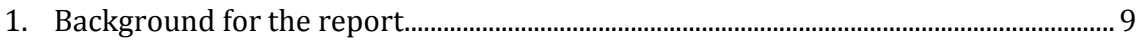

2. Facts and figures on gender, education and population flows....................................11

3. Why is it important to include considerations of gender and equal treatment?

4. Similarities and differences among the Nordic countries............................................23

5. Existing literature and research - a summary ............................................................25

5.1 Young people in peripheral areas feel a great pressure to leave their local communities

5.2 It is often related to education or work when young people (especially women) decide to move......................................................................25

5.3 The place where the young people live forms the premises for their opportunities and educational choices............................................26

5.4 The place where the young people live also forms the premises for their commitment and desire to obtain an education ................................26

5.5 Geographical mobility is often linked to social mobility..................................27

5.6 Both the gender segregated educational choices and the gender segregated labour market are pronounced in the Nordic peripheral areas

5.7 Young women in peripheral areas experience fewer opportunities within the local labour markets, but also in terms of local associational life, leisure activities and cultural events.

5.8 The strong gender segregation of the Nordic labour markets reinforces the negative development trends in the periphery .....................29

5.9 Peripheral areas contain potentially inherent patriarchal structures which push away young women.

5.10 Some men in peripheral areas are particularly affected by the restructuring of the local labour markets and the changing living conditions

5.11 Some men in the peripheral areas have made conscious choices to live there - and remain in their local communities because this is where they thrive

6. Ideas for policy-makers and other stakeholders plus selected examples from practice

6.1 Theme: Lack of/limited access to education in peripheral areas. ..................34

6.2 Theme: Restructuring of the labour markets in the peripheral areas.........38

6.3 Theme: Women find life in peripheral areas less attractive. ..........................41

6.4 Theme: Labour supply is too narrow in the peripheral areas.......................43

6.5 Theme: The stigma of the peripheral areas affects the youth of both

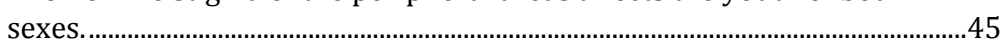

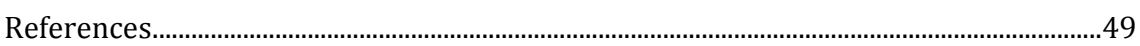

Resumé - DK 



\section{Résumé - UK}

During the Danish Presidency for the Nordic Council of Ministers in 2015, attention was drawn towards challenges and best practice examples in relation to gender, education and population flows in peripheral areas throughout the Nordic countries - Norway, Denmark, Sweden, Finland, Iceland and the autonomous countries, Greenland, the Faroe Islands and Aaland. This report briefly summarises the findings covered in existing Nordic research and literature within the field, and further presents the experience and professional responses, which were presented during a knowledge-sharing seminar for different stakeholders across the Nordic countries. Thus, the report provides a condensed presentation of the knowledge available within the field, while also providing a more practical source of inspiration for policymakers, other authorities and actors with respect to future actions in this area - locally, regionally, nationally and across the Nordic region. 



\section{Background for the report}

During the Danish Presidency for the Nordic Council of Ministers in 2015, attention was drawn towards challenges and best practice examples in relation to gender, education and population flows in peripheral areas throughout the Nordic countries - Norway, Denmark, Sweden, Finland, Iceland and the autonomous countries, Greenland, the Faroe Islands and Åland.

As part of this, a report including existing research and literature in the field was produced along with an inter-Nordic seminar held on 17 June 2015 in Nuuk, Greenland. Attending the seminar was a number of political actors, government officials and representatives from various Nordic educations and professional organisations. In the preparation of the report and the planning of the seminar, a wide range of Nordic researchers and other players in the field were contacted to uncover knowledge and experiences from the different countries.

The decision to focus on gender, education and population flows has been motivated by the fact that the Nordic region's peripheral areas are all characterized by a number of similar challenges; challenges which include changing living conditions, stagnant or negative economic growth, low growth, decline in the number of jobs (especially in traditional male occupations) and not least depopulation and out-migration (especially among women in peripheral areas). These challenges are of great importance for the people living in peripheral areas, and also for the long-term viability of the areas and their cohesion (Faber, Pristed Nielsen \& Bennike 2015). As part of writing the main report and at the seminar in Nuuk, it was confirmed that the above mentioned challenges have the attention of numerous stakeholders throughout the Nordic countries. A fact which stresses that common dialogue and exchange of experience across the Nordic countries is conducive to meeting these challenges.

The present report summarises the findings and conclusions which are covered in the existing Nordic research and literature within the field, as well as the experience and professional responses, which were presented during the course of the common dialogue and exchange of experience facilitated by the Nordic Council of Ministers in 2015. The idea is that this report will provide a condensed presentation of the knowledge available within the field, while providing a more practical source of inspiration for 
policymakers, other authorities and actors (e.g. in the municipal administrations, educational institutions, workplaces, among interest organisations, trade unions, etc.) with respect to future actions in this area - locally, regionally, nationally and across the Nordic region. For those who want to gain a broader introduction to research and literature in the field, and a deeper knowledge of the underlying issues surrounding gender, education and population flows, we kindly refer to the main report. ${ }^{1}$

1 The main report on research and literature on the field was written by Centre for Equality, Diversity and Gender (EDGE) at Aalborg University and was conducted in the period January 2015 to May 2015. The report is available in both Danish and English. Both reports can be downloaded online:

Danish version: "Sted, (U)lighed og Køn - En kortlægning af udfordringer og best practices i relation til køn, uddannelse og befolkningsstrømme i Nordens yderområder" (2015):

Available here: https://www.divaportal.org/smash/get/diva2:840467/FULLTEXT01.pdf

English version: "Place, (In)Equality and Gender - A Mapping of Challenges and Best Practices in Relation to Gender, Education and Population Flows in Nordic Peripheral Areas" (2015):

Available here: http://norden.diva-portal.org/smash/get/diva2:840484/FULLTEXT01.pdf 


\section{Facts and figures on gender, education and population flows}

This section provides a brief overview of the main differences and similarities between the Nordic countries based on facts and figures about gender, education and population flows across the Nordic region.

The overview is mainly based on figures and information from Nordregio (Nordic Centre for Spatial Development), who among other things produces statistical overviews of the Nordic region's peripheral areas. Nordregio has compiled and published a series of maps, which for example show net-migration and the out-migration in the periphery by gender, and depicts education trends in the Nordic region. These maps - several of which are reproduced on the following pages - provide a visual overview of the situation in the Nordic region's peripheral areas, and they portray some of the specific geographic challenges.

The maps also illustrate that there is a very concentrated and more or less uniform trend in all the Nordic countries, and thus illustrate clearly the challenges which the Nordic countries are facing when it comes to population flows and gendered trends in the peripheral areas.

Did you know that...

- The Nordic countries are facing a number of the same challenges, concerning gender, education and population flows in the peripheral areas.

- There is a connection between a local area's size and its gender composition: a small community will often have a deficit of women compared to the number of men.

- Even though both men and women are moving towards the larger cities, the trend is more significant among women.

- The development tendencies in the Nordic peripheries contain a strong gender dimension, which is often overlooked. 
In relation to population density and moving patterns, map $n r$. 1 shows that the tendency of depopulation in peripheral areas is repeated in all the Nordic countries. The dark blue colour on the map illustrates the population growth in major cities and urban areas, while peripheral areas are characterized by the grey colour; signifying population decline. Thus, the map shows "growth areas", where the increase of the population corresponds to about $80 \%$ of the total increase in the last ten years. In relation to Denmark, Finland and Sweden, two-three growth areas can be located, while there are several growth areas in Norway. However, about $90 \%$ of population growth Iceland is located around Reykjavik.

Figure 1: The map shows population change in the Nordic Region in the period 2003-2013

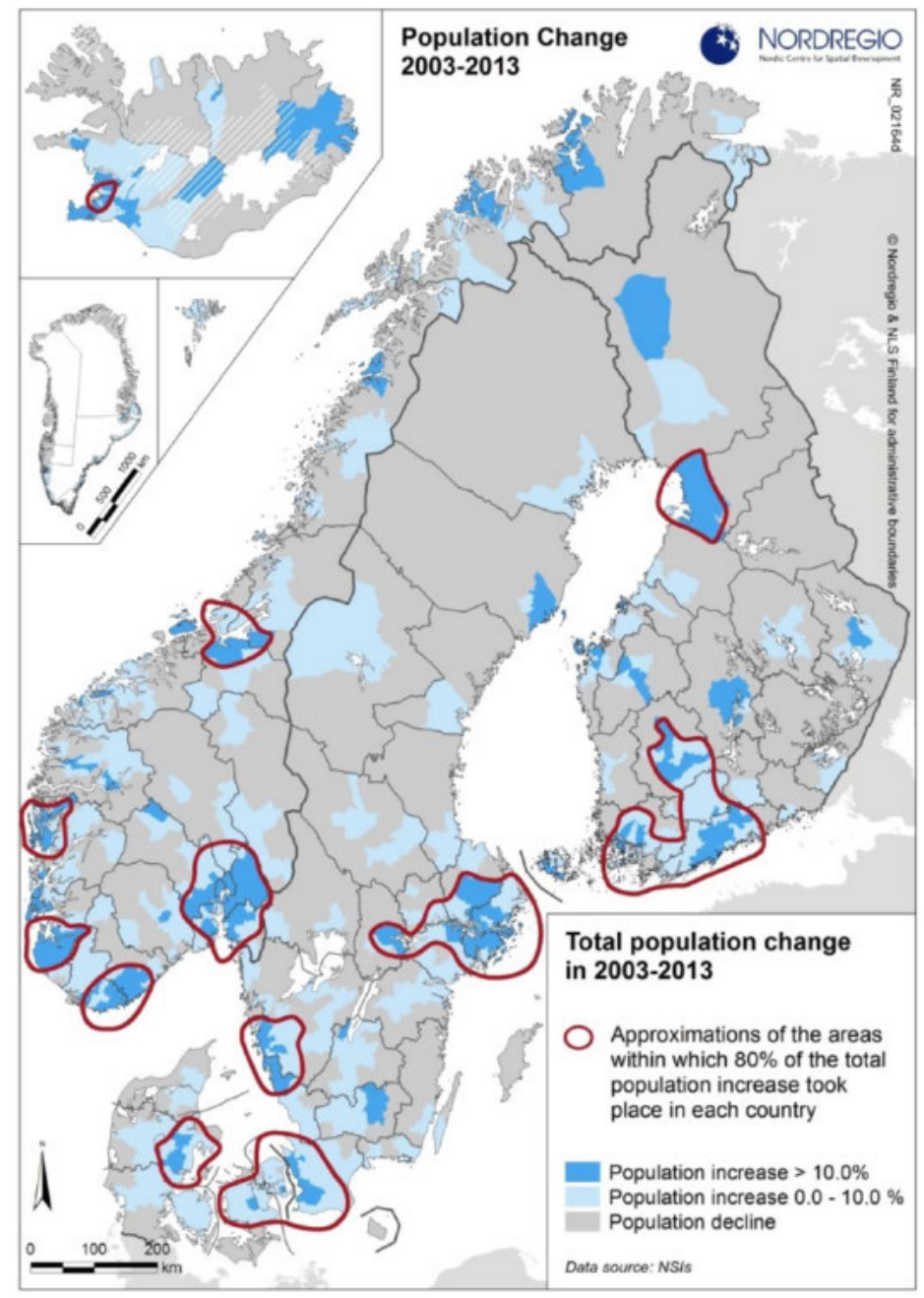

Source: NordRegio 2014.

Design Johanna Roto. 
Map nr. 2 (next page) shows the number of higher educational institutions per municipality (size of circles - the bigger the circle, the higher number of educational institutions), the proportion of the population with tertiary education per region (yellow shade - the darker shade, the higher the level of education), and the proportion of women with higher education per municipality in which a higher education is located (the colour in the circles - the more red a circle, the higher the proportion of women). Compared to municipalities hosting higher education institutions, the map shows that the proportion of women with higher education tend to be higher in metropolitan areas and in major cities, which visually captures that women in the North largely are moving from peripheral areas and into the cities. Conversely, it is observed that the municipalities that only have a single educational institution located away from the major cities generally have more men with higher education. Hence, there appears to be a synergistic effect, whereby not only the location of a single institution, but also that more educational institutions are placed near each other affects the gender composition of the municipality.

The underlying explanation is probably that the rate of urbanization (i.e. the larger a city) affects both the number of women and the number of educational institutions positively. In Iceland, Greenland and the Faroe Islands, all municipalities with higher numbers of educational institutions have a majority of men with higher educations. Based on conclusions from the main report and the seminar, there is a tendency (which the map also illustrates) that men, if there are educational opportunities within the region, are making use of these, whereas women often move to the larger cities to enrol in a higher education (for the latter three countries it applies that mainly women are moving to other countries in the Nordic region to obtain an education) (see e.g. Haagensen 2014 and Rafnsdóttir 2010). In relation to education in Iceland, Greenland and the Faroe Islands, an additional factor in the gender distribution can be explained by the fact that a large part of the educational institutions focus on maritime training and education, which often attracts more men than women. 
Figure 2: The map shows the number of higher educational institutions per municipality, the share of population with a higher education per region, and the share of women with a higher education per municipality institution is present

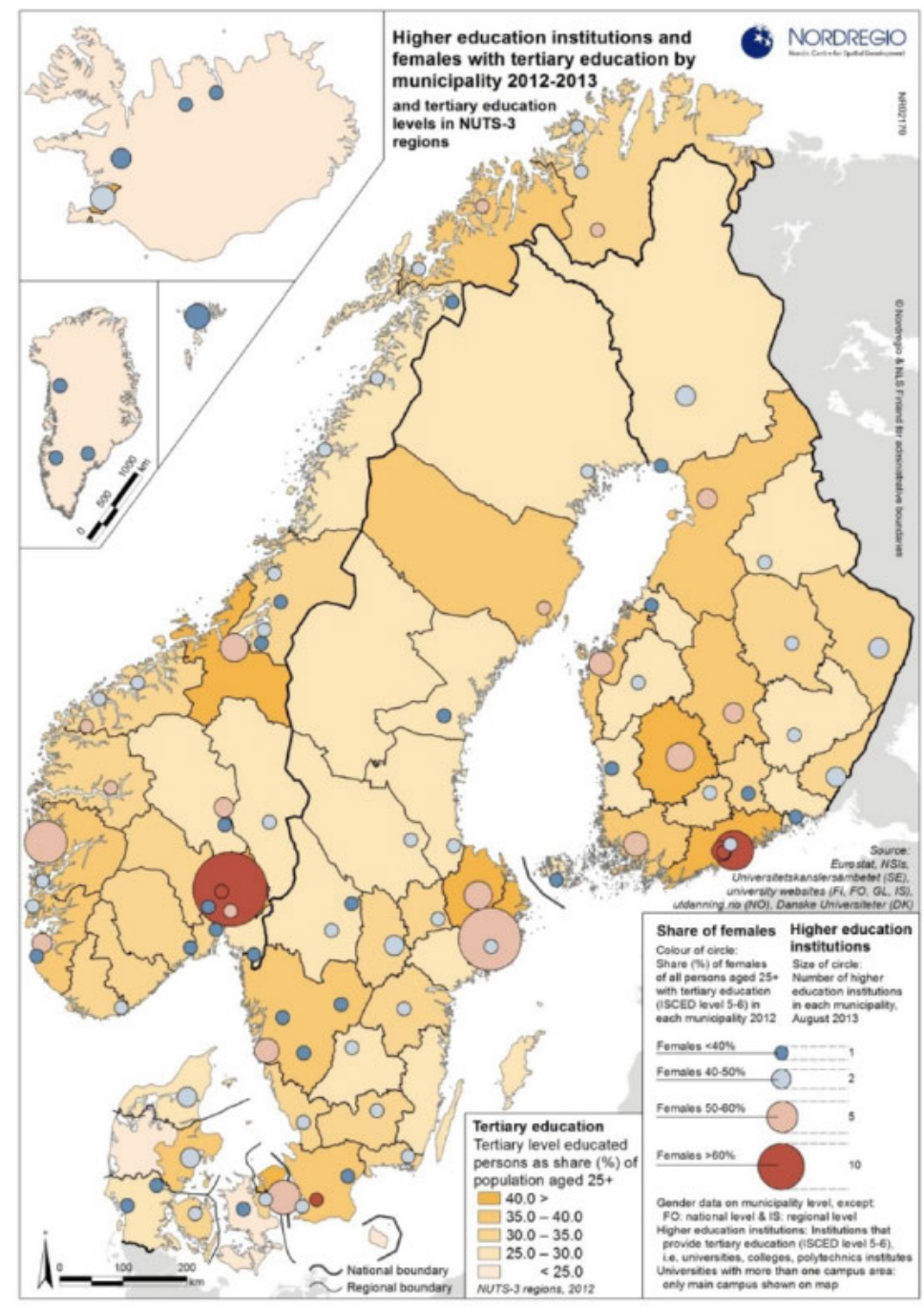

Source: NordRegio 2014.

Design Linus Rispling. 
When looking at the population flows in peripheral areas in the form of in-and-out-migration, maps 3 and 4 illustrate that there is a clear tendency for young people across the Nordic countries to move from the peripheral areas ( $\operatorname{map} 3$ ), and that very few families with small children migrate to these areas, which causes the peripheral areas to gradually depopulate and thereby also experience an increase in the general population age (map 4).

Figure 3: The map shows out-migration in the Nordic Region in the period 2006-2010

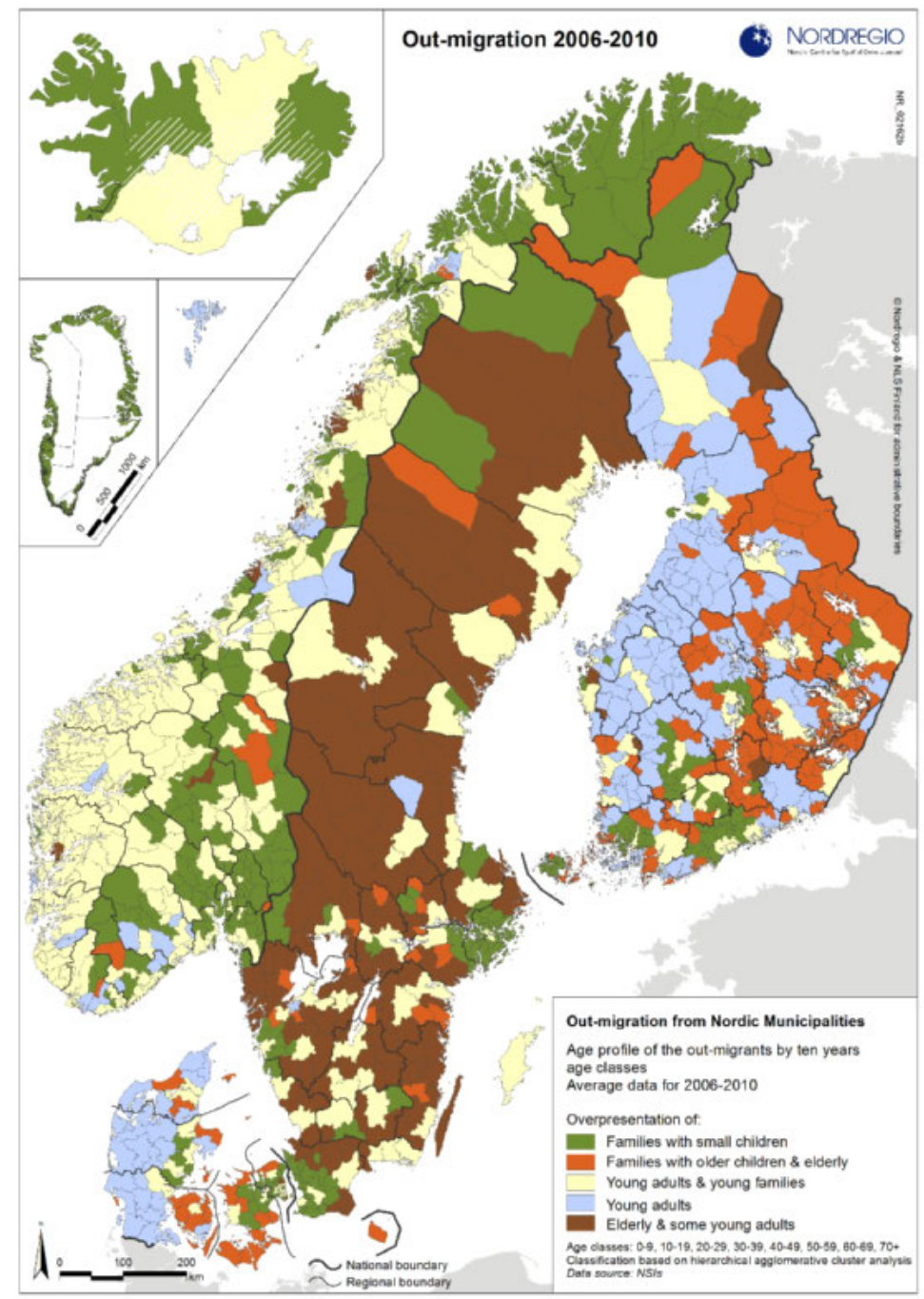

Source: NordRegio 2014.

Design Johanna Roto. 
Figure 4: The map shows in-migration in the Nordic Region in the period 2006-2010

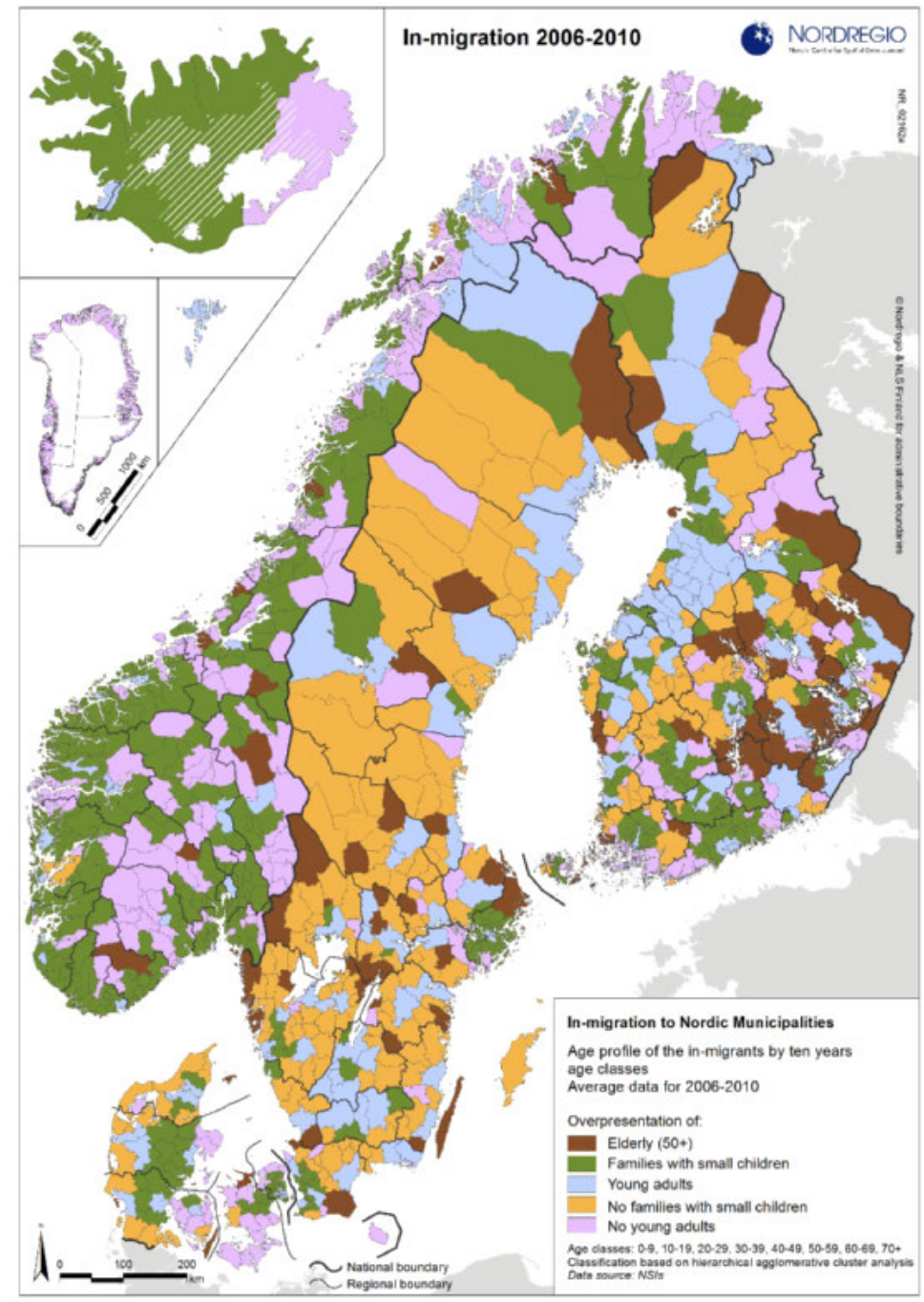

Source: NordRegio 2014.

Design Johanna Roto. 
Map 5 show that migration patterns among men and women are the same, but that the intensity of women who move from peripheral areas is higher, and that this is a trend, which is repeated in all the Nordic countries. On both maps, the red colours indicate depopulation tendencies, while the blue colour marks the population growth, and the yellowish areas have a more or less stable population size. As mentioned, the general trends are the same for both men and women, as evidenced by the colours of on the maps.

Figure 5: The map shows the net-migration for men in the period of 209-2011

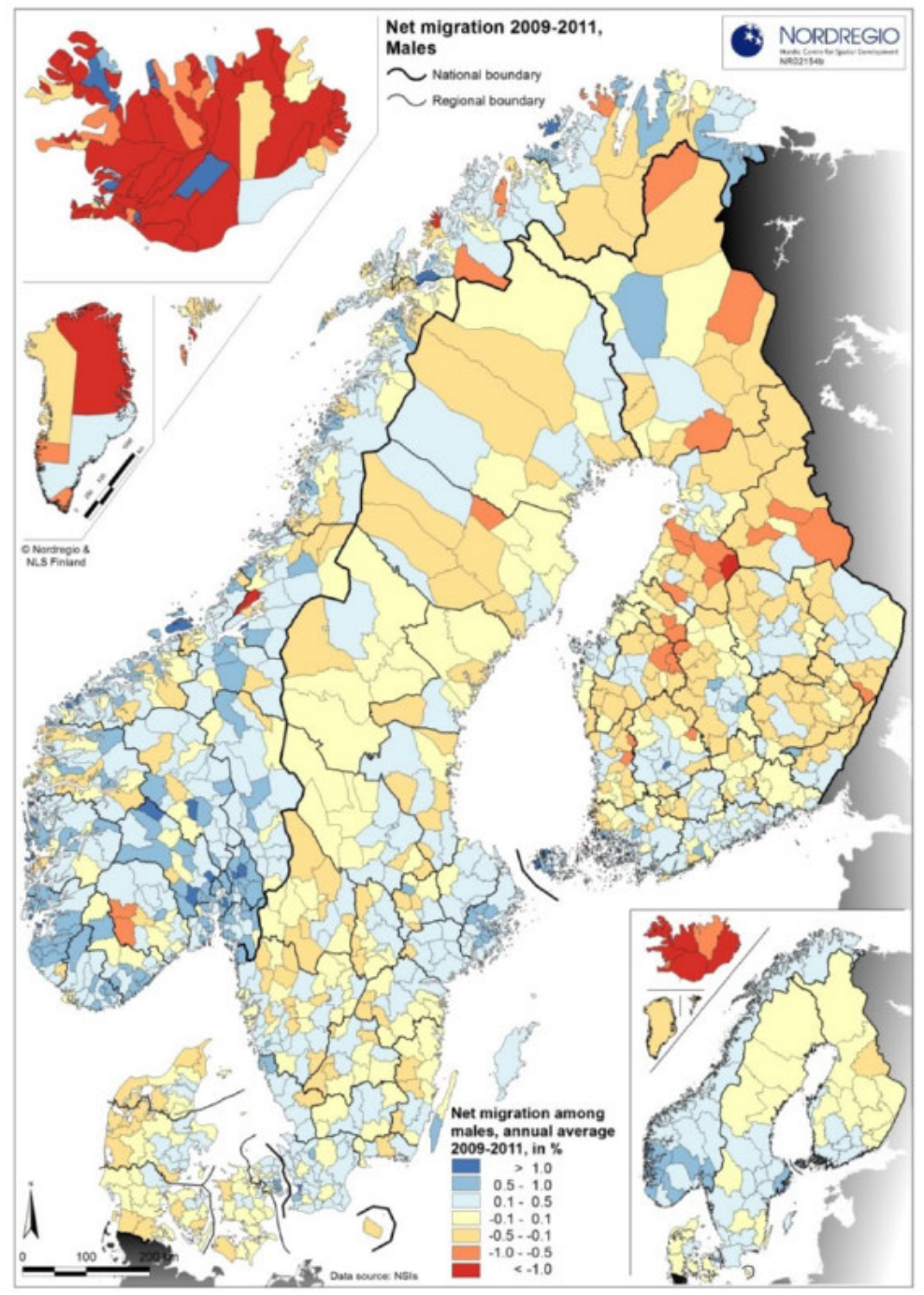

Source: NordRegio 2014.

Design Johanna Roto. 
Map 6 the darkest colours dominate: the dark red colour (i.e. depopulation) and the dark blue colour (i.e. population growth) - in other words, the overall picture of the Nordic women's migration patterns are more extreme than the pattern seen among men in map 5 where the colours are overall more douched. As an example, the largest net-migration among women in Denmark is to Copenhagen and Aarhus (the second largest city in Denmark), respectively. The overall result across the Nordic region is a predominance of women in the cities and a majority of men in peripheral areas.

Figure 6: The map shows net-migration for women in the period 2009-2011

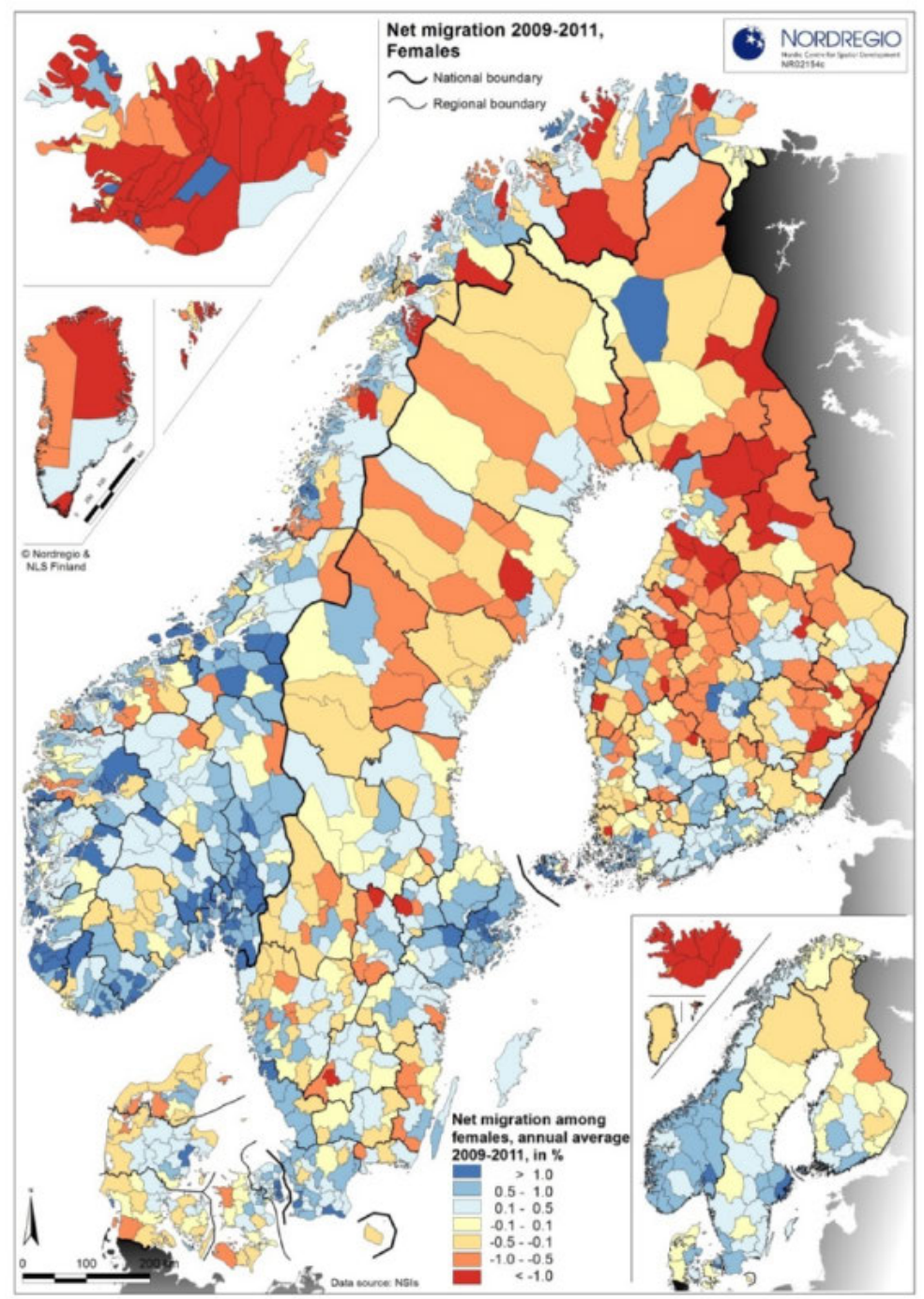

Source: NordRegio 2014.

Design Johanna Roto. 
As seen above, the trends are similar across the Nordic countries, but particularly pronounced in the West Nordic Countries (Greenland, Faroe Islands and Iceland) (see e.g. Rafnsdóttir 2010). Highly detailed studies have been carried out in Greenland, not only in relation to the actual population flows, but also the reasons for moving (see e.g. Rasmussen 2010). The Greenland Mobility Study confirmed that there are significant gendered differences behind the reasons for wanting to migrate. Women indicated that they wanted to move to gain better access to education, to get access to more culture and leisure activities and to get away from social control in the smaller communities and provide increased opportunities for their children. The study showed that men in Greenland, in contrast, are more motivated by opportunities in the labour market. A reason for Greenlandic men to choose to move could be that they feel that there are better and more business opportunities for them and/or their partner elsewhere. Common for respondents from both sexes in the Mobility Study was that they wanted to reside in an area where the wages are higher, with increased opportunities for public transportation and a variety of other public benefits, for example, health and education facilities (Rasmussen 2010). 



\section{Why is it important to include considerations of gender and equal treatment?}

The main report, which included research and literature in the field, underlined that it is important to include a gender perspective if you want to understand the trends that characterise the Nordic region's peripheral areas. This is underlined by the facts and figures which were illustrated in the different maps above.

In some respects, it is not a new problem that women in peripheral areas in the Nordic region are moving towards the cities; actually research from the past 100 years points to this issue. ${ }^{2}$ The recent global trends, however, have contributed to the negative trends intensifying, which has given rise to concepts such "flight of women" and "female deficit". At the same time, research and public debates have recently focused on the men who remain in the periphery. Here, it has for example been argued that the restructuring of labour markets in the periphery (and a marked decline in the number of so-called "male occupations") have put the more traditional forms of masculinity under pressure (Faber, Pristed Nielsen \& Bennike 2015) (see also Baagøe Nielsen 2011 and Gaini 2006).

The common challenges, which the peripheral areas face are a result of structural, economic and socio-cultural changes. The challenges include changes in local business traditions and changing educational patterns in peripheral areas, challenges concerning transport, social infrastructure, local attachment or lack thereof, labour market segregation and gender-segregated education choices, change of recruitment patterns in different sectors of the labour market, and so on. These are all challenges, which should not and cannot be analysed nor solved without including a gender perspective (Faber, Pristed Nielsen \& Bennike 2015).

The development in the peripheral areas must be seen and understood in relation to the notion that places can be "gendered", as research within the field indicates. The point is that the places where men and

2 See Ravenstein 1885 for original observation, but also for example Bjarnason and Thorlindsson 2006, and Giskeødegård and Grimsrud 2014 for contemporary perspectives. 
women live, and the spheres they move in (e.g. in the family, in educational institutions, the workplace, etc.), all are rooted in specific geographical locations which are embedded with different meanings and notions of what is considered socially acceptable. By extension, we can talk about the geographical locations being part of defining the possibilities that exist, including the degree of individual space of action that men and women experience (Faber, Pristed Nielsen \& Bennike 2015) (see also Dahlström 1996; Stenbacka 2011; Rafnsdóttir 2010).

As this report illustrates, it is import when addressing the challenges of the Nordic region's peripheral areas to focus on integrating gender and equality perspectives at all levels - national, regional, municipal and local. This is already to some extent part of the work carried out in the Nordic countries by focusing on gender mainstreaming (or "equality assessment", which is the Danish name). However, Rönnblom (2005) highlights in her analysis of gender mainstreaming efforts in Sweden and Norway that gender and equal treatment not always are thought of as an integral element of the regional/municipal development efforts. She finds that gender equality in this effort almost exclusively is considered as something related to women and not both women and men, which means that a number of gender issues are often analysed and addressed too narrowly, for example in relation to educational measures, employment initiatives, traffic planning, leisure activities, and so on. 


\section{Similarities and differences among the Nordic countries}

As stated in the previous section on facts and figures, there are a number of relevant similarities across the Nordic region, which makes it beneficial to share common experiences and engage in comparative discussions. The challenges facing the Nordic Region in relation to peripheral areas and in relation to gender, education and population flows have many dimensions - both at an individual, group and community level, and in the interaction between the levels. The relevant similarities across the different Nordic areas are reflected in the educational system, on the labour market and generally in the local communities in the Nordic peripheral areas.

The Nordic countries are not only bound together by history, but also widely share political and cultural roots along with a similar set of values, which is reflected in the shape of the welfare state and the types of welfare services seen throughout the Nordic countries. The Nordic countries are also known historically to have a high degree of equality between the sexes and, compared to many other European countries, to have a strong focus on equal opportunities for men and women/boys and girls (see e.g. Siim and Stoltz 2015).

When one considers the Nordic countries together, however, there are also a number of contrasting differences, for example in terms of geographical distances, population density, distribution of natural resources, the speed at which the education and labour markets are changing, differences in the characteristics of the local labour markets and the sectors which dominate, the organisation of social infrastructure and the types of local businesses, associations and employment. In light of this, there are variations in experience and practice in political measures across the Nordic countries (Faber, Pristed Nielsen \& Bennike 2015) (see also Haagensen 2014).

For Denmark, Norway, Sweden and Finland it is the case that the discussion about gender, education and population flows generally is tied to specific issues linked to particular and often sparsely populated, peripheral areas. Here focus is predominantly on the internal migration patterns among people, and especially on how young people move within the countries and/or commute to an education (see e.g. Bloksgaard, Faber and Hansen 2013). In some remote areas, the Danish, Swedish and Norwegian 
youth do not have access to secondary education, or only access to a limited selection of secondary schools, which in practice may force them to leave home at a very early age (see among others Paulsgaard 2012 and 2015 and Bjarnason and Thorlindsson 2006). There is no doubt that the geographical distances are much more pronounced in Norway and Sweden, compared to e.g. Denmark. This probably also explains why there is a strong research tradition when it comes to discussing the problems surrounding gender and population flows related to educational choice particularly in Norway and Sweden. For Iceland, Greenland, the Faroe Islands and Åland, on the contrary, the issues are to a lesser extent related to regional/local variations within the countries - but still with a focus on the differences between urban and rural, centre and periphery. In these areas, the main issue in regards to population flows and education is that it often entails national emigration - leading to depopulation and decline in the number of children born, as many young people never return to their local communities after having obtained an education abroad (see e.g. Hovgaard, Eythórsson and Fellman 2004 and Rafnsdóttir 2010). 


\section{Existing literature and research - a summary}

A number of recurring themes and trends which were identified in the main report on research and literature related to gender, education and population flows are summarized below. ${ }^{3}$

\subsection{Young people in peripheral areas feel a great pressure to leave their local communities}

The literature shows that young people - especially women - in the Nordic peripheral areas base their choice to leave on a number of very different reasons. They are often either forced to move and/or feel a pressure to leave their communities. Literature in the field stresses that young people - both men and women - leave their homes in peripheral areas, not only because they want to see and experience the world or because moving away from home is a natural part of growing up, but also because they feel it is impossible for them to stay either due to lack of educational choices and job opportunities, or because they find the local communities in peripheral areas limiting or claustrophobic.

\subsection{It is often related to education or work when young people (especially women) decide to move}

The report shows that young people in the Nordic region's peripheral areas have different perceptions in terms of whether or not they believe there is a place for them in their local communities in the long term. In relation to this, gender seems to play a significant role, since cross-Nordic literature stresses that changing living conditions in peripheral areas

${ }^{3}$ The summary in this section is an extract from the main report "Place, (In)Equality and Gender - A Mapping of Challenges and Best Practices in Relation to Gender, Education and Population Flows in Nordic Peripheral Areas" (2015), written by Faber, Pristed Nielsen \& Bennike. 
causes young women to experience limitations associated with their gender, for example when assessing their future opportunities in the local labour markets. This seems, to a greater extent than is the case for the young men, to collide with the young women's concerns about how they would like to live in the long term, and what is actually possible in their local communities. It is clear from the report that young women in the periphery focus on higher education to a greater extent than young men. The literature also indicates that women's desire to move from peripheral areas can to some extent be linked to a desire by women to gain access to more and equal opportunities - in education, work and in everyday life as well as a greater degree of freedom from traditional gender roles and norms (this point will be elaborated later).

\subsection{The place where the young people live forms the premises for their opportunities and educational choices}

Although the Nordic countries at a national level share a political ideal of equality, the report shows that context-specific variations exist. In this sense, the standard of equal opportunities for all in the Nordic education systems does not always correspond with the actual situation in the Nordic region's peripheral areas. The report indicates that across the Nordic region, it is important to ask whether men and women effectively have equal rights and are able to achieve the education/training they want. The place where young people live puts limitations on what is realistic and accessible, which means that the place where you live is part of shaping the opportunities that the young people relate to. An example of this is that some boys/young men in the periphery opt out of taking a secondary education (e.g. vocational training), because there are no institution near their home which offers this type of training.

\subsection{The place where the young people live also forms the premises for their commitment and desire to obtain an education}

The place where young people live is part of setting the premise for their opportunities not only in regard to their educational and work life choices, but also, to some extent, in terms of shaping their commitment and aspiration for learning. In some peripheral areas, the local labour 
market requires less education and the choice not to engage in further studies can therefore be viewed as sensible and rational. Furthermore, the report highlights that the culture within educational institutions is perceived by some students as "foreign" because their identities are rooted in a community where focus is on a different type of values and forms of cultural/social capital. The research in the field indicates that especially young men are potentially experiencing a cultural collision; a collision between, on the one hand, the values and the perception of what constitutes "the good life" of young men, and, on the other hand, the educational and career-oriented narrative presented in the media and by politicians on the national stage, which states that young people must be adaptable and mobile (i.e. willing to relocate) and that academic education is the only way forward.

\subsection{Geographical mobility is often linked to social mobility}

As shown by research in this area, education is central to young people's life course both in the form of adjustments to the surrounding labour market, way of life, lifestyle and identity. For young people from the Nordic peripheral areas and from small urban communities in these areas, choosing a higher education often means moving away from home. At the same time, geographic mobility is in many cases linked to social mobility, as a number of the young people from peripheral areas come from homes and/or local environments where taking a higher education has not been customary. There is a distinct gender perspective attached to this issue; however, Swedish research suggests that a weak connection to the labour market and a low level of education are not necessarily viewed as a problem for young men in the periphery, who have a working class background. It has been highlighted that these young men themselves often believe that they are better off by staying in the local communities rather than moving; because the culture they like, and the privileges they have as men in the local area, do not have the same status outside the peripheral areas. 


\subsection{Both the gender segregated educational choices and the gender segregated labour market are pronounced in the Nordic peripheral areas}

The local (and regional) labour market in peripheral areas provides a framework within which young people evaluate their options. The literature suggests that it is not only educational opportunities but also opportunities in the labour market, which affect young people's (especially young women's) desire, to move away or perhaps later return home. Research shows that young men often are more closely linked to the types of occupations and lifestyles that characterize peripheral areas, even though emphasis on retraining men to work in the so-called "female" occupations is also needed. In order to ensure that a higher number of young women choose to stay in the peripheral areas or choose to move back to their local communities after graduation, it is necessary to create local employment opportunities in peripheral areas that require higher education.

\subsection{Young women in peripheral areas experience fewer opportunities within the local labour markets, but also in terms of local associational life, leisure activities and cultural events}

When young women in the periphery often find that they have fewer opportunities than young men, it is not only centred on the lack of relevant job opportunities in the peripheral areas. Other aspects are emphasized in the research as well; for example, the amount and type of voluntary or leisure activities are important for young people's choices on whether to stay in peripheral areas or move - the literature points out that the activities which young men typically are involved in (e.g. hunting, fishing and outdoor recreation or for example through local professional communities), seems to link them more closely to the local area than the activities that young women are involved with. 


\subsection{The strong gender segregation of the Nordic labour markets reinforces the negative development trends in the periphery}

A common feature across the Nordic countries' labour markets is a strong tendency of gender segregation - more pronounced in some countries than others, but nevertheless there is a general tendency for women working in the public sector and men in the private sector - and particularly the primary sector (agriculture, forestry, and mining) are largely dominated by men. This gendered segregation of the labour market in several Nordic peripheral areas has been a factor that has contributed to especially men having been hit hard by the economic crisis, as the number of traditional male occupations has decreased significantly within several areas.

\subsection{Peripheral areas contain potentially inherent patriarchal structures which push away young women}

In some of the literature, it is emphasized that peripheral areas tend to push women away due to inherent patriarchal structures. Thus, it is for example concluded that several of the young women consider moving away from the small communities in peripheral areas and obtaining an education crucial for shaping their own identity and creating a lifestyle detached from local cultural and structural limitations; including gendered expectations of women's roles and responsibilities, relationships and motherhood - gendered norms which these young women experience as limiting their space for action.

\subsection{Some men in peripheral areas are particularly affected by the restructuring of the local labour markets and the changing living conditions}

Research suggests that men in peripheral areas seem to be particularly affected by the restructuring of the labour market and the changing conditions of life that characterises the peripheral areas in all the Nordic countries. Furthermore, it has been highlighted that the recent years' financial crisis has pushed this development further along, which from a 
gender perspective has led scholars to talking about not simply a recession, but a "mancession" (Weyhe 2011). This notion should be linked with today's focus on mobility and flexibility, which according to the research is part of creating a negative discourse about the men who remain in the peripheral areas. Research suggests that there are men in peripheral areas who are experiencing ambivalence, and some men also exhibit signs of what in the literature has been described as melancholic masculinity (McDowell 2003). This should be seen in the context that many of the young men in the periphery grow up with a traditional gendered understanding that masculinity and hard physical work are closely linked. With the restructuring of the local labour markets and the rising unemployment in the traditional male professions, this understanding is challenged.

\subsection{Some men in the peripheral areas have made conscious choices to live there - and remain in their local communities because this is where they thrive}

In the discussion of a female deficit which characterises many of the Nordic region's peripheral areas, it is also relevant to stress that the aim it not simply to lure newcomers (especially women) to peripheral areas, but that focus should also be on protecting the individuals (especially men) who continue to reside in the periphery, and in connection with this, produce more positive images of the periphery. The tendency for young men to have a greater degree of place attachment than the young women to the periphery is not just related to a particular type of pattern of life, particular professional communities, local business traditions or to leisure activities that harmonize well with traditional male interests - research also suggests that young men remain in their local communities because they prefer the country life, and because they feel that there are some values which they can only/best practice there. The fact that the men who remain in the periphery may happen to have made a conscious and reflexive choice of residence, education and occupation are to a lesser extent part of the cross-Nordic debate. 
Did you know that... - about women/femininities i the Nordic peripheral areas

- That research long has suggested that women in sparsely populated areas in the Nordic countries have a higher tendency than men to move to the urban centres.

- That many young women in the peripheral areas experience that the local communities have more opportunities for young men when it comes to education, occupation and leisure.

- That many women move to the cities to study and afterwards experiences that it is difficult to return to their local areas because the job opportunities in the periphery does not match their qualifications.

- That local gender norms can be a contributing factor for women who want to move to the cities, as they consider the cities to be more modern and gender equal.

- That women who appreciate traditional gender norms are more likely to see a future for themselves in the local communities.

\section{Did you know that... - about men/masculinities in the Nordic peripheral areas}

- That research has shown that among certain young men in the peripheral areas there is a tendency not to prioritise school because academic knowledge is not considered an asset in the local labour market.

- That there is a tendency for young men in the peripheral areas compared to young women to appreciate where they live, e.g. because of the different activities that they are able to take part in (for example fishing, hunting and other outdoor activities), and this attaches the young men to the local area.

- That a number of young men consider it a positive choice to stay in their local communities.

- That it is often considered natural for young men in the peripheral areas to take over their father's occupations.

- That the prevalent masculine culture in some of the Nordic region's peripheral areas, which is based on hunting, outdoor activities and craftsmanship, can make it difficult for men with an academic education to feel fully accepted in the local community.

Source: Faber, Pristed Nielsen \& Bennike 2015. 



\section{Ideas for policy-makers and other stakeholders plus selected examples from practice}

In the previous section, we have presented a summary of the issues which existing research and literature in this field has previously identified as being of importance. We will now take this a step further and, based on the cross-Nordic dialogue and knowledge-sharing, present how this knowledge can potentially be translated into action, for example in relation to establishing national education policies or implementing initiatives within each of the Nordic countries. As part of the cross-Nordic dialogue and knowledge-sharing, various topics and focus areas were highlighted where it was considered not only possible but also feasible to focus on national/regional/municipal/local development from a gender perspective. Drawing attention to such focus areas could potentially affect young peoples' experience of room for manoeuvre in relation to choice of education, occupation and where to live, and thus help address some of the challenges faced by the peripheral areas. The exposition below is based on the identification of five themes, all containing specific gender issues in relation to education, work, recreation, population flows and identity in the Nordic region's peripheral/remote areas. For each theme, suggestions for action as well as practical examples are provided. These are summarized on the basis of what came to light during the cross-Nordic dialogue and exchange of experiences.

The five themes are:

1. Lack of/limited access to education in peripheral areas.

2. Restructuring of the labour markets in the peripheral areas.

3. Women find life in peripheral areas less attractive.

4. Labour supply is too narrow in the peripheral areas.

5. The stigma of the peripheral areas affects the youth of both sexes. 


\subsection{Theme: Lack of/limited access to education in peripheral areas.}

Problem: Increased demands and expectations of formal education as well as gender-segregated education choices.

In some of the Nordic region's peripheral areas, the young people do not have access to neither secondary education nor higher education, or they only have access to a limited range of educations and/or fields of study, which in practice may mean that they are forced to leave home at a very young age. Previous studies show that in particular young women in peripheral areas leave home early (Faber, Pristed Nielsen \& Bennike 2015). However, it must be said that there are different traditions across the Nordic countries; for example, in both Greenland, Iceland and the Faroe Islands the tradition is that young people of both sexes leave the islands (primarily to go to Denmark) to get an education. But where many of the young people from Greenland and the Faroe Islands do not return home again, in Iceland young people more often return home to use their acquired education.

The lack of - or limited access to - education in peripheral areas across the Nordic countries is problematic, because politically, socially and among young people themselves there are increasing demands and expectations of a formal education. The requirements for education are present both at the local, regional and national labour market, and it is also part of a general (and global) trend. This increased demand for formal education is related to the fact that today even traditional jobs within for instance agriculture and fishing requires a different set of skills than in the past, including knowledge of economics, management, security, etc.

The young people in the peripheral areas compare themselves with young people living elsewhere, e.g. by way of the Internet and social media, and the global/national narrative is that formal education is a requirement today. It may be difficult for the young people having to leave home at an early age (often around 16 years) in order to be able to get an education, which may result in some rejecting the idea altogether, or resulting in higher drop-out rates - both at great cost to the young people themselves, for their communities and for society as a whole.

Possible areas for action: Decentralization of educational institutions, long-distance learning, focusing on transportation/commuting, special assistance to young people who have to move far.

An important conclusion that recurs across all of the Nordic countries in relation to education and in relation to counteracting unintentional gendered consequences, is the importance of focusing of the geographical 
location of the different educational institutions in the political planning processes. For example, in Denmark boys commute longer than girls because the vocational educational institutions (typically with a predominance of male students) are geographically far more dispersed than the upper secondary schools, and often the boys also commute to and from the place where they go for internship. This may hamper their opportunities to do leisure activities in their spare time, and at the same time it might also prevent some boys from getting an education. When decisionmakers and other stakeholders discuss the possibility of centralizing and merging educational institutions into fewer but larger units, it is important to take these conclusions into consideration. This is also underlined by the fact that previous research indicates that more boys than girls tend to drop out of their education if they are forced to stay in school boarding houses or to commute long distances to complete an education. In sum, merging and centralizing educational institutions is likely to more or less directly dis-favour boys/young men.

As already mentioned, previous research shows that young men throughout the Nordic countries to a greater extent than girls are attached to their local areas, for example through leisure activities, and that the young men also are more likely to find a foothold in traditional occupations like fishing and forestry. The fact that the boys, socially and professionally, are more linked to the local area than the girls, also gives them a greater incentive to stay.

In addition, the location of an educational institution can act as a driver for various types of development in remote areas - for example, this can be identified in Akureyri (Iceland), where the local University has grown from originally 4 employees and 50 students in 1987 to $169 \mathrm{em}$ ployees and 1,703 students in 2014. At the same time the northeast region, which is where the University of Akureyri is located, is the only region in Iceland, which has had a net immigration of Icelandic women. In the cross-Nordic dialogue a representative from KUN (Center for sharing of knowledge and equality in Nordfold) argued that it is important to keep in mind that an active local effort and placement of educational institutions in local areas can form the basis for a positive local development.

Long-distance education in remote areas is an initiative that some researchers argue can have a positive effect in relation to discouraging emigration among young people, because young people are thus able to take part of or all of their secondary or higher education by way of distance learning, while keeping their attachment to the local areas. Additionally, long-distance learning can contribute to educating the local population to 
ensure that skills are present in relation to undertaking new jobs in upcoming sectors, such as within the health care system, which is generally growing at the local level in all the Nordic countries. There are many good experiences with long-distance learning of different kinds across the Nordic countries. In the 1970s, the focus was on decentralizing educational institutions in the Nordic countries, for example, in Norway, Denmark and Finland local universities were established to remedy emigration and raise the level of education outside the metropolitan areas. It remains clear the case that it is in particular technical educations which attract men, and that women are now generally over-represented in higher education across the Nordic countries.

Urbanization is a trend that is well known in all the Nordic countries. Nurturing place attachment among the young people in the peripheral areas is therefore a major factor in getting them to stay in these areas or to come back after having completed an education in one of the major cities. As part of the cross-Nordic dialogue it was mentioned that the so-called "Salmon-effect" no longer works (a pattern whereby the young people move to the cities, but return home to breed i.e. have children), and that it is therefore important to make sure that children and young people feel attached to their local communities in other ways. At the same time, it is of course important to support them in their decision to move, but if their attachment to the local area is strong, there is a greater likelihood that they will return after graduation. It is therefore important that local areas continuously signal that they want young people even while they are away, and that there is a need for them in the local area, when they complete their education.

\subsubsection{Concrete ideas related to lack of/limited access to education in peripheral areas}

- It is important to identify gender issues in relation to the provision of education in the peripheral area across the Nordic countries, including gender mainstreaming the geographical location of the educational institutions, transportation and commuting opportunities, etc. This could be done by taking into account the various educational preferences of both sexes when planning educational offers.

- Gender-segregated choices of education etc. requires awareness of the importance of gender. In the design of educational offers, it is essential to focus on how to prevent gender gaps in peripheral areas, as well as in the centres. For example, this means that educational 
institutions should increasingly try to appeal to both boys and girls, and that there should be a conscious effort to prevent genderstereotypical expectations, norms and ideals for boys/girls, young men/women. In particular, the latter should be taken into account in the efforts carried out in educational institutions among teachers and counsellors. It is especially here that it is possible to affect the strong gender segregation in young people's educational choices.

- Providing higher education by way of long-distance learning so that students can stay in their local area while being enrolled in an education may be important in order to make it possible for young people to stay in their communities and at the same time make it possible for them to get an education. There is also the option of using long-distance learning in secondary education.

\subsubsection{Examples from practice related to lack of/limited access to education in peripheral areas}

- An example of a long-distance learning initiative is the LOSA-project from Norway. LOSA stands for "Local education in cooperation with the labour market" ("Lokal Opplæring i Samarbeid med Arbeidlivet") and the project offers decentralized Internet-based education for young people in rural communities. Students receive Internet-based guidance from teachers/trainers, through MSN, Skype, email, video link and telephone, but can also occasionally meet in a classroom with a larger group to receive more traditional classroom training. LOSA is offered both in traditional secondary education, and in a number of vocational training programmes. The project does not directly counteract the gender segregation of educational choices, but at least studies are provided to attract both girls and boys.

- In Sweden they have tried to educate young boys with a low educational level, by providing them with the possibility of taking a so-called "college year" where young boys have the opportunity to obtain or add to the skills and competencies they lack, while receiving unemployment benefits.

- Both from Northern Norway and Sweden there are examples of involving the local labour market, which has an interest in making the young people stay in the region. This can serve as a tool if local employers can contribute e.g. with internships during the course of a study, or if they can offer part-time work in combination with, for instance, the young people enrolling in a youth education part-time. 
- Regarding the need for special support to young people who have to move far away from home to get an education, it was during the cross-Nordic dialogue mentioned that in Finland there exists an additional student benefit for students who come from remote areas, so that they can afford to return home to visit while studying in the cities. This may not only contribute to helping young people in relation to homesickness etc. but also ensure that they retain affiliation to their local areas.

\subsection{Theme: Restructuring of the labour markets in the peripheral areas.}

Problem: Globalisation and the financial crisis has put traditional male occupations under pressure.

Globalisation and the financial crisis has put traditional male occupations under pressure. Due to outsourcing, global competition and demands for efficiency, for example, in the processing industry many "male jobs" have vanished and traditional trades such as agriculture and fisheries do not offer the same employment opportunities as previously. This has led to talk about the global financial crisis from 2008 onwards as "mancession" (Weyhe 2011) instead of the "the recession". Furthermore, there is no doubt that global processes create a bias in employment possibilities in particular for those, men as well as women, living in peripheral areas. Women in particular dominate the public sphere for instance in the service sector as well as in the healthcare system, and typically these jobs are not outsourced to the same extent as some of the male jobs (albeit the second wave of the financial crisis also led to savings in the public sector). Therefore, a number of initiatives (both at the local, regional and national level) have focused on recruiting more men into the service sector and the health care system. These are two sectors in the Nordic labour markets that are less under pressure, partly because of a generally aging population throughout the Nordic countries.

Possible areas for action: Break with gender segregation both in education and the labour market. Work on softening perceptions of "female jobs" and "male jobs", respectively. Focus on retraining and upgrading the skills of men living in peripheral areas.

It is important to include gender in labor market strategies. As long as the job market remains highly gender segregated, it is difficult to curb the effects of structural changes for one sex or the other, and balance the supply of labor in the periphery. One of the most striking examples in the 
Nordic region of the effects of gender segregated labor markets is found in Åland. Here, there has been great upsurge in "female job", and thus the number of employees in the public sector grew by a whopping $20 \%$ in the period 2000-2010. In contrast, there has been a large decline in employment in the shipping industry of $8 \%$ - and precisely the shipping industry is of utmost importance for the Åland labour market (ÅSUB 2013). All in all, this means that the men - far more than the women - have been affected by fluctuating economic trends within the private sector.

For Greenlandic men, for example, the "mancession" has been related to a lack of jobs in traditional "male sectors" such as fishing (Weyhe 2011). In the cross-Nordic dialogue, it was pointed out that the labor market in Greenland is highly segregated, and that in the period 2008-2013 700 jobs in fishing have disappeared. The jobs disappear from the fishing sector due to streamlining and centralization (e.g. of fish processing, but also because the boats are getting bigger and better). Meanwhile, $59 \%$ of jobs in the public sector are held by women. In addition, the amount of jobs in the public sector is growing, causing women to "win" 240 jobs over the past years. Furthermore, many "male jobs" in Greenland are also seasonal (house construction and fishing is at a standstill during winter), which means that Greenland has approximately 4900 unemployed men during the winter, while in August and September 2000 of these who have found jobs again. This was one of the points that were highlighted in the crossNordic dialogue, in this case by a representative of the Greenlandic Ministry of Industry, Labour and Trade.

\subsubsection{Concrete ideas related to the reduction in the number of traditional "male jobs"}

- Considerations about how jobs in the public sector should be geographically distributed and/or what kinds of jobs should close down, should be accompanied by considerations of potential gendered implications; including considerations of whether the decision will primarily affect male or female workers.

- Jobcentres, trade unions and employers can work together to break the strong gender segregation in the labour market - for example, by highlighting role models or examples of men and women who have chosen gender untraditional in their working lives.

- Another issue concerns "melancholic masculinity" (McDowell 2003). This concept aims to capture the problem that some men in the peripheral areas associate masculinity with traditional forms of business and work, which can tie them to ideas about education and 
career choices that do not lead to job security. Ideas as to how to tackle the problem of melancholic forms of masculinity was put forward in the cross-Nordic dialogue, such as highlighting role models i.e. by introducing young boys to men who have had success with their work in non-traditional jobs.

- In continuation of the above, the lack of male teachers and pedagogues in remote areas is an important area to look at, as men in educational institutions and kindergartens have a significant impact on boys and other young men in remote areas, as they can act as role models and provide advice and guidance. One priority could be to focus on the opportunities for training and education in later life for men who want to be, for example, kindergarten teacher or health worker.

\subsubsection{Examples from practice related to the reduction in the number of traditional "male jobs"}

- The Icelandic trade unions point to the possibility that the trade unions actively include requirements for training funds when negotiating agreements, while also highlighting how the Icelandic trade union movement has actively supported the establishment of educational institutions in peripheral areas, especially in order to create locally based opportunities for continuing education.

- Another approach found in Norway, is the project Men in Health ("Menn I Helse") which aims at retraining men from typical "male jobs" to take over jobs in the care sector. This project has been quite successful when assessing the number of men who have completed a health professional education and subsequently found employment. Through targeted recruitment campaigns and the use of role models, this project has helped to change the image of jobs in the care sector, and stressed that this is also a sector which contains jobs for men.

- In Denmark social clauses have been introduced in some sectors to ensure that local employment opportunities are available for instance in relation to local public construction projects. This means that companies know that if they want to win a contract on a public construction project, they must be willing to offer apprenticeships for local young people. 


\subsection{Theme: Women find life in peripheral areas less attractive.}

Problem: The women in remote areas demand more education and employment opportunities as well as a wider range of culture and leisure activities. They also demand less social control and liberation from traditional gender norms.

As mentioned previously, research in this field documents that the youth (and especially the young women), point to educational and work opportunities when explaining why they want to move away. This points to the importance of ensuring a broader variety of opportunities and job creation in remote areas. The mapping of the literature on trends in the labour markets in the periphery emphasizes that an important key to creating change in education patterns and population flows, may lie in softening notions of "male jobs" and "female jobs". If local labour markets can dismantle these boundaries, it would both expand the supply of experienced job and training opportunities for young men and women, and also contribute to the break with traditional gender norms which the young women otherwise seek through moving to larger cities.

Another issue is the fact that young women in remote areas often find that they have fewer opportunities than young men, when it comes to the type and amount of voluntary or leisure and cultural activities. Such activities play an important role in young people's choice of whether to stay in remote areas or to move - and existing research literature points out that the activities that the young men take part in seem to attach them more to the place than the activities that the young women participate in. At the same time, research from e.g. Denmark, the Faroe Islands and Iceland point out that for some young women, it also plays a part in their decision to leave that they want to get away from existing traditional gender norms, which they find limiting. Women's motives for moving from peripheral areas hence relate not only to education and jobs, but also that they experience a lack of opportunity to influence the local community and local decision-making processes.

Possible areas for action: It is important to be able to offer more varied opportunities and types of jobs in remote areas. Broader cultural offers should be recognized as important, and there should be conscious effort to discuss existing gender norms. Research is lacking about the unwritten rules and norms governing the relations between men and women in remote areas.

It is important to include the whole range of life in the small communities when responses to emigration, and for example seek to provide a wider range of cultural offers and an active discussion of local gender 
norms and expectations. The mapping of existing research did not lead to the identification of practical examples that relate directly to this issue. Neither did the cross-Nordic dialogue provide examples of action in this area, but based on reports from Åland Statistical Bureau, it is evident that leisure activities are to a large extent gender segregated, and research from both Greenland and the Faroe Islands indicate how cultural life plays a role for women when deciding where to live.

\subsubsection{Concrete ideas related to making women find life in peripheral areas more attractive}

- Efforts should be made locally to create new stories about the peripheral areas as places containing relevant opportunities for both women and men. It is essential to break with these stereotypical "pictures" that children and adolescents are presented with in relation to the gendered choices of hobbies and leisure activities already at an early stage in the educational system.

- Research, especially from the Faroe Islands and Greenland, has suggested that it may be a problem that many local councils and municipal bodies do not have female members or only have very few female members. This can contribute to invoking a feeling among women that they have no possibilities for influencing their local communities.

- It is relevant to perform gender mainstreaming in relation to leisure activities and cultural offers. There are differences in the respective leisure and cultural activities offered in cities and in remote areas, and this fact contains a gender dimension. Thus, when cultural and leisure oriented activities are planned in the peripheral areas, gender is an essential category to include in the planning. Here, gender mainstreaming can be used as a method to study the differences. Concretely, regional, municipal and local actors providing leisure and cultural activities and cultural should be asked to consider how their offers appeal to men and women, as well as to boys and girls. 


\subsubsection{Examples from practice related to making women find life in peripheral areas more attractive}

- Over the years, the Nordic countries have in different ways worked to break down the gender segregated labour market, for instance with a focus on getting more women into so-called "male occupations" and more men into so-called "female occupations". In the cross-Nordic dialogue it was emphasized that experiences from Norway show that the single-sex structures tend to be reproduced as soon as the focus is removed. It was reported that public authorities in Norway put great focus on getting women into male occupations for a period of time, which also included a lot of volunteers who served as role models. The initiative had great power and had a positive effect on both the gender segregated educational choices and the gender segregated labour market. The conclusion of the project was that it is possible to change the traditional gender segregated choices of both education and jobs, and national/regional/local initiatives have an effect - but it requires a lot of effort and continuity.

\subsection{Theme: Labour supply is too narrow in the peripheral areas.}

Problem: Lack of jobs that match their skills lead women in particular to leave the peripheral areas.

The labor supply is often very narrow in remote areas with few jobs in the tertiary sector (i.e. in trade and services) and especially few jobs within knowledge-based work, which typically requires a higher education. As more young women than young men obtain a university education throughout the Nordic countries, this means that labor markets in remote areas often simply do not contain jobs that match women's qualifications, which causes them to opt out of these areas.

Possible areas for action: Decentralization of knowledge-based jobs within the public sector, support entrepreneurship, creation of "SMARTwork" centres.

It is important to implement efforts to diversify the supply of labour in the periphery, i.e. create jobs that are not similar to those that already exist locally. Research indicates that it is not the size of a locality but its internal variation in the supply of labor which is the decisive factor for the creation of a "female deficit" or not (see Hamilton and Otterstad, 1998). 
Therefore, it is essential to establish highly skilled jobs in the local community and/or strengthening the possibilities of remote working places or "SMART-work" centres, as women generally have obtained a higher level of education than men, and thus are more likely to wish to stay in local communities if more highly skilled jobs are available.

\subsubsection{Concrete ideas related to making the labor supply wider in the peripheral areas}

- In the cross-Nordic dialogue, a representative from the University of the Faroe Islands pointed out that the problem of "female deficit" concretely could be countered if the individual Nordic countries developed a "mobility policy". This would allow, for instance, living in Tórshavn, but working in Copenhagen or Reykjavik. In the Faroe Islands there are already people who live and work in this way, but it is difficult with the current system - particularly in relation to spreading the current system to different sectors. For example, one has to be a craftsman to get tax deduction under current Faroese rules. It was suggested that this could be a policy area that could be addressed jointly on a Nordic level, thereby facilitating opportunities to stay in outlying areas while having an exciting and relevant job.

- Various possibilities exist for improving the infrastructural conditions for starting a business and/or working from a local base for example, by means of fast broadband connections and shared office spaces.

\subsubsection{Examples from practice related to making the labor supply wider in the peripheral areas}

- An example for possible copying within other contexts was experiences with supporting entrepreneurship courses. These are generally found in several Nordic countries, for example Brautargengi which is an Icelandic project specifically targeting female entrepreneurs. The course has helped to strengthen young women's awareness of the possibilities for starting their own business as an alternative career path - even in remote areas. Thus, the project has helped to maintain some women in remote areas that otherwise would have moved to larger cities to find jobs.

- SMART work centers may be found in several places across the Nordic countries, but often in urban areas, although there is great potential also outside the major cities. An example of this can be 
found in the "distance worker house" in Tranum in Denmark, created under the motto of Tranum as "Europe's fastest village".

\subsection{Theme: The stigma of the peripheral areas af- fects the youth of both sexes.}

Problem: The negative publicity and image of peripheral areas enhances young peoples' desire to move away.

Both from the mapping as well as the cross-Nordic dialogue, it is evident that various negative notions and discourses about the peripheral areas of the Nordic countries and the people who live here are prominent. This negative stigma is not only rooted in the media; it is also heard regularly among politicians, practitioners, researchers and, not least, it is recorded by the people, especially the young people, who live in remote areas. Within research, it is common to refer to so-called "supra-local currents"; these include ideas of what constitutes "the good life" and the stories attached to remote areas, and often repeated in both print, digital and social media and the web in general. Precisely the Internet and social media are important arenas in young people's daily lives, and they are for many young people - also in peripheral areas - an important frame of reference for how they see themselves, and the thoughts they have about their future (Faber, Pristed Nielsen \& Bennike 2015).

The stigma of the peripheral areas affects both young girls and boys, and the negative publicity enhances young peoples' desire to move away. In the cross-Nordic dialogue, it was confirmed that in remote areas across the Nordic region, it is common to come across the idea that it is "necessary" to move away to be "modern". The negative stories about the Nordic peripheral regions indicate that they are perceived as places that must change (be "modernized"), rather than places to be nurtured and preserved. Research indicates that the perception of peripheral areas by young people is often more important than the factual conditions. In the cross-Nordic dialogue and exchange of experiences, it was stressed that promoting alternative images and possibilities can contribute to new patterns and strategies developed among the youth in remote areas - perhaps especially among young men.

Possible areas for action: There is a need for new stories about the peripheral areas: stories about these areas as places to be nurtured and preserved. Research indicates that some (especially men) choose to remain living in remote areas because they actually thrive here. 
It is important to nuance the stories about life in remote areas, and is important to remember that some (men) actively choose to stay because they thrive precisely here, and that it is therefore also important to avoid creating a narrative that the only way forward for the young is to leave to get an education and a job. It is therefore important that the stigma of the peripheral areas is addressed so that there can be a change of attitude. However, this is a long term process and it is therefore important that there is political support for strengthening the peripheral areas, which includes making decisions about investments in infrastructure, leisure facilities, internet availability, day-care, social institutions and decentralization of all welfare offers, etc. At the same time, it is important to emphasize those role models which articulate good examples. Here, the school and the teachers have an important task in having an eye for the individual child or young person, and not blindly passing on existing gender norms and expectations. In addition, the peripheral areas share a responsibility to speak up and highlight the benefits of living in smaller municipalities/areas both in terms of leisure and working life.

In the cross-Nordic dialogue it was discussed how - over the course the past twenty years - there has been a shift in relation to policy and work on regional development, for example in Sweden. This is a shift which the mapping also identifies in many of the other Nordic countries although Norway here differs with a more decentralized approach. The point is that focus seems to have changed from a previous national level focus in the individual Nordic countries on ensuring equal opportunities and equal living conditions in all areas of the respective countries, to a current situation in which focus across the Nordic countries - though growth in all regions continues to be an important theme - often still translates into a clear prioritization of metropolitan regions and peri-urban areas.

\subsubsection{Concrete ideas related to creating a new narrative about the peripheral areas}

- The mapping and cross-Nordic dialogue suggest that efforts at all levels (national, regional and local) should be directed towards changing the narrative about the Nordic region's peripheral areas so that other images and opportunities are promoted as a way to contribute to the development of new patterns and strategies for both sexes. 


\subsubsection{Examples from practice related to creating a new narrative about the peripheral areas}

- A clear example of a successful "new narrative" was presented as part of the cross-Nordic dialogue. A representative from Ærø Municipality in Denmark reported that such an initiative has been launched to increase settlement on the island, including specifically the idea of setting up a so-called "bosætningshus" [settlement house] where individuals or families who are considering moving to the island can apply for being allowed to stay for up to 3 months, in order to "try out island life" without tying themselves by investing in a house from day one. Both on Ærø and in relation to other similar initiatives in Denmark, meetings have also been arranged where "new" and "old" residents can meet each other.

- Both in Sweden and Denmark, interest groups have formed who together try to defend the interests of some of the less densely populated areas. The association "Hele Sverige Ska Leva" [the Whole of Sweden Must Live] and "Sammenslutningen af Danske Småøer" [the Association of Small Danish Islands] were thus represented in the cross-Nordic dialogue and reported, amongst other issues, about branding strategies and attempts to create common (local) political solutions for some of the challenges they faced.

- The education program "West Nordic Master" is an example of a program provided in cooperation between universities in the Faroe Islands, Iceland, Northern Norway and Greenland. This education focuses its content specifically on the challenges facing the Nordic peripheral areas, including the gendered dimensions of these challenges.

- It is relevant to mainstream a gender perspective into initiatives and projects that aim to make the peripheral areas more attractive and thus attract newcomers. An example is "Tiltakssonen" in Finnmark and North-Tromso, Norway. This project involves student loan relief or cancellation for highly educated, who settle in Finnmark and North Troms after graduation (as more women have an education and thus a loan, this initiative contains an inherent gender dimension). The project also includes higher child allowances and supplements for day care staff in remote areas (this relates to both parents, but research shows that especially women prioritize the quality of welfare provisions when they make decisions about where they want to settle). 



\section{References}

Baagøe Nielsen, S. (2011). Nordiske mænd til omsorgsarbejde!: - en forskningsbaseret erfaringsopsamling på initiativer til at rekruttere, uddanne og fastholde mænd efter finanskrisen. Roskilde: VELPRO - Center for Velfærd, Profession og Hverdagsliv.

Bjarnason, T. \& Thorlindsson, T. (2006). Should I stay or should I go? Migration expectations among youth in Icelandic fishing and farming communities. Journal of Rural Studies 22 (3): 290-300. http://dx.doi.org/10.1016/j.jrurstud.2005.09.004

Bloksgaard, L., Faber, S. T., \& Hansen, C. D. (2013). Drenge i Udkanten - Køn, Stedtilknytning og Uddannelse. In C. H. Jørgensen (ed.) Drenge og maskuliniteter $i$ ungdomsuddannelserne, (1st edition, p. 87-208). Roskilde Universitetsforlag.

Dahlström, M. (1996). Young women in a male periphery - Experiences from the Scandinavian north. Journal of Rural Studies 12 (3): 259-71. doi:10.1016/ 0743- 0167(96)00018-6.

Faber, S. T., Nielsen, H. P., \& Bennike, K. B. (2015). Sted, (U)lighed og Køn - En kortlægning af udfordringer og best practices i relation til køn, uddannelse og befolkningsstrømme i Nordens yderområder. TemaNord, 2015:557. Copenhagen: Nordisk Ministerråd. http://dx.doi.org/10.6027/TN2015-557

Gaini, F. (2006). Once Were Men. Maculinities among young men in the Faroe Islands. In Fróðskaparrit 54 [Annales Societatis Scientiarum Færoensis]. Torshavn: Faroese University Press.

Giskeødegård, M. F. \& Grimsrud, G. M. (2014). Kjønnsperspektiv på rekruttering av innbyggjarar til Møre og Romsdal. Rapport nr. 52. Møreforskning, Højskulen i Volda, Møre og Romsdal Fylkeskommune.

Haagensen, K. M. (2014). Nordic Statistical Yearbook 2014. Vol. 52. Nord 2014:001. Copenhagen: Statistics Denmark - Nordic Council of Ministers. http://dx.doi.org/10.6027/Nord2014-001

Hamilton, L. C. \& Otterstad, O. (1998). Sex Ratio and Community Size: Notes from the Northern Atlantic. Population and Environment 20 (1): 11-22. http://dx.doi.org/10.1023/A:1023347817418

Helvé, H. (red.). (2003). Ung i Utkant - Aktuel forskning i glesbygdsungdomar. TemaNord 2003:519. Copenhagen: Nordisk Ministerråd.

Hovgaard, G., Eythórsson, G. T., \& Fellman, K. (2004). Future Challenges to Small Municipalities: The Cases of Iceland, Faroe Islands and Åland Islands. Stockholm: Nordregio, Nordic Centre for Spatial Development.

McDowell, L. (2003). Redundant Masculinities? Employment change and white working class youth. Oxford: Blackwell Publishing.

Paulgaard, G. (2012). Geography of opportunity. Approaching adulthood at the margins of the northern European periphery. In U.-D. K. Bæck \& G. Paulgaard (eds.) Rural futures?: finding one's place within changing labour markets (p. 189-216). Stamsund: Orkana Akademisk.

Paulgaard, G. (2015). Place Attachment, Unemployment and Masculinity: Young Men in the High North In S. T. Faber \& H. P. Nielsen, Remapping Gender, Place and Mobility - Global Confluences and Local Particularities in Nordic Peripheries (207-20).

Farnham: Ashgate Publishing. 
Rafnsdóttir, G. L. (red.). (2010). Kvinder og Velfærd $i$ Vestnorden. TemaNord 2010:578. København: Nordisk Ministerråd. http://dx.doi.org/10.6027/TN2010-578

Rasmussen, R. O. (red.) (2010). Mobilitet i Grønland: Sammenfattende analyse. Stokholm: NordRegio.

Ravenstein, E. G. (1885). The Laws of Migration. Journal of Statistical Society, $n r .48$ : 167-227.

Rönnblom, M. (2005). Letting Women in? Gender Mainstreaming in Regional Policies. NORA - Nordic Journal of Feminist and Gender Research 13 (3): 164-74. http://dx.doi.org/10.1080/08038740600587711

Siim, B \& Stoltz, P. (2015). Particularities of the Nordic: Challenges to Equality Politics in a Globalized World. In: S. T. Faber \& H. P. Nielsen Remapping Gender, Place and Mobility - Global Confluences and Local Particularities in Nordic Peripheries (p. 19-35). Farnham: Ashgate Publishing.

Stenbacka, S. (2011). Othering the rural: About the construction of rural masculinities and the unspoken urban hegemonic ideal in Swedish media. Journal of Rural Studies 27 (3): 235-44. http://dx.doi.org/10.1016/j.jrurstud.2011.05.006

Weyhe, T. (2011). Finanskrisen og arbejdsmarkedet i Grønland. In S. B. Nielsen. Nordiske mænd til omsorgsarbejde!: - en forskningsbaseret erfaringsopsamling på initiativer til at rekruttere, uddanne og fastholde mænd efter finanskrisen. Roskilde: VELPRO - Center for Velfærd, Profession og Hverdagsliv.

Ålands statistik och utredningsbyrå (2013). Kvinnors Och Mans Val Och Villkor I Samhalle Och Arbetsliv. Publiceras Som Bilaga till Landskapsbudgeten 2013. 


\section{Resumé - DK}

Under det danske formandskab for Nordisk Ministerråd i 2015 blev der sat fokus på udfordringer og gode praksiseksempler i relation til køn, uddannelse og befolkningsstrømme i yderområderne i hele Norden - Norge, Danmark, Sverige, Finland, Island og de selvstyrende lande Grønland, Færøerne samt Åland. Denne opsamlingsrapport sammenfatter de resultater samt konklusioner, som er afdækket i den eksisterende nordiske forskning og faglitteratur på området samt præsenterer de erfaringer og faglige indspil, som kom frem på et seminar for vidensdeling for forskellige interessenter på tværs af Norden. Rapport giver således en komprimeret præsentation af den viden, der foreligger på området, og fungerer samtidig som et mere praksisorienteret inspirationskatalog til politiske beslutningstagere, andre myndigheder og aktører i forhold til en fremtidig indsats på området - lokalt, regionalt, nationalt og på tværs af Norden. 
Nordic Council of Ministers

Ved Stranden 18

DK-1061 Copenhagen K

www.norden.org

\section{Gender, Education and Population Flows}

During the Danish Presidency for the Nordic Council of Ministers in 2015, attention was drawn towards challenges and best practice examples in relation to gender, education and population flows in peripheral areas throughout the Nordic countries - Norway, Denmark, Sweden, Finland, Iceland and the autonomous countries, Greenland, the Faroe Islands and Aaland.

The present report summarises the findings and conclusions which are covered in the existing Nordic research and literature within the field, as well as the experience and professional responses, which were presented during the course of the common dialogue and exchange of experience. 